\title{
K PÔVODU MORAVSKÉHO RASTISLAVA Z JAZYKOVEDNÉHO HLAADISKA
}

\section{On the Origin of Rastislav of Moravia From a Linguistic Point of View}

\author{
Martin Diweg-Pukanec
}

DOI: 10.17846/CL.2020.13.1.44-50

\begin{abstract}
DIWEG-PUKANEC, Martin. On the Origin of Rastislav of Moravia From a Linguistic Point of View. This paper deals with three names of the successor to the throne after Mojmír I, ruler of Great Moravia, in the historical records: ${ }^{*}$ Rastislava, ${ }^{*}$ R'ästicu and ${ }^{\star}$ Rasticb. The Late Proto-Slavic personal name ${ }^{\star}$ Rastislavz of the Great Moravian ruler is doubtful. The names ${ }^{\star}$ R'ästicu and ${ }^{*}$ Rasticb are Central Slovak because Proto-Slavic ${ }^{*}$-itjo > West Slavic (including Central Slovak) $-i c b$ and Proto-Slavic ${ }^{*}$ orst- $>$ South Slavic as well as Central Slovak Rast-, and Central Slovak ra- > r'ä- > rä- (cf. Central Slovak räst', riast). This fact has many historical consequences, the most important of which is the origin of the socalled Rastislav of Moravia.
\end{abstract}

Keywords: dialectology, Great Moravia, Proto-Slavic, Slavic languages, Slovak language, onomastics

\begin{abstract}
Abstrakt: DIWEG-PUKANEC, Martin. K pôvodu moravského Rastislava z jazykovedného hladiska. Tento článok sa zaoberá troma menami následníka trónu po Mojmírovi I., vládcovi Velkej Moravy, v písomných prameňoch: ${ }^{*}$ Rastislavo, ${ }^{*}$ 'ästicb a ${ }^{\star}$ Rasticb. Praslovanské osobné meno ${ }^{*}$ Rastislavø velkomoravského panovníka je neisté. Mená ${ }^{*}$ R'ästicb a ${ }^{*}$ Rasticb sú stredoslovenské, pretože praslovanské *ittjo > západoslovanské (vrátane strednej slovenčiny) -icb a praslovanské * orst- > južnoslovanské a stredoslovenské Rast- a stredoslovenské ra- > $r$ 'ä- > rä- (porov. stredoslovenské räst', riast'). Z tohto faktu vyplýva viacero historických skutočností, z ktorých najdôležitejšou je pôvod takzvaného Rastislava z Moravy.
\end{abstract}

Klúčové slová: dialektológia, Vel'ká Morava, praslovančina, slovanské jazyky, slovenčina, onomastika

V našom nedávnom článku $K$ menám priamej línie Mojmírovskeho domu pre časopis Acta onomastica (Pukanec 2020, 185-193) sme sa snažili poukázat na správny historickojazykovedný výklad osobných mien pravdepodobnej priamej línie domu Mojmírovcov, vládcov štátneho útvaru 9. - 10. storočia (nielen) v povodí rieky Moravy, ktorý sa volal Morava, ale tiež Velká Morava (ojedinelé označenie Konštantína Porfyrogeneta) či nezriedka Moravy (plurál vo viacerých jazykoch, duál dvakrát v slovanskom). Predpokladáme v ňom, že otec najvýznamnejšieho vládcu tejto ríše Svätopluka I. bol najskôr synom Mojmíra I. a volal sa bud'Mojmír, alebo Svätopluk, na čo poukazuje predovšetkým to, že Svätopluk mal synov s oboma týmito menami, ale priamu rodovú spojitost medzi nositel'mi mien môže podla nás navyše naznačovat sémantika oboch mien, ked'že je rovnaká: meno Mojmír pochádza z ${ }^{\star}$ Mojiměrz „slávny, znamenitý svojimi“ a Svätopluk zas zo *Svętopzlkz/*Svętěpzlkz, čo podobne znamená „slávny, znamenitý svojimi“. 
Rastislav ako zrejme synovec (nepos) Mojmíra I. ani Slavomír, ktorí sú nositelia zvyšných dvoch známych kniežacích antroponým uvedeného štátu, príp. nitriansky Pribina, súčasník Mojmíra I., nemusia nevyhnutne predstavovat hlavnú líniu Mojmírovcov, ak za jej ústredného predstavitela či zakladatela považujeme Mojmíra I. V tomto článku sa teda zameriame na mená vedlajšej línie Mojmírovcov, ktorej najvýznamnejším predstavitelom musí byt’ v rámci tohto ponímania predovšetkým Rastislav, ale $\mathrm{z}$ onomastického hladiska je ním možno aj Pribina. Slavomíra ako epizodického hrdinu vel'komoravských dejín, ktorý navyše ani nemusel byt' kniežatom v pravom zmysle slova, ale len vodcom vzbúrencov, v tomto príspevku opomíname.

Ako sme už v úvode článku uviedli, Morava sa označovala nielen singulárovo, ale i plurálovo a najmä duálovo Moravy (historický nominatív duálu by bol Moravě). Metod mal byṫ takto arcibiskup Vyšňuju Moravu (MMFH II 1967, 165), resp. Moravu (MMFH II 1967, 253), teda práve dvoch naddunajských Moráv (pozri Stanislav 1978, 51, 66). Moravy mali asi i špecifickejšie názvy, aby sa vzájomne nejako odlišovali. Tieto sú dôležité, lebo ukazujú, že jazykovo neboli tieto dve kniežatstvá úplne jednotné. Špecifikácie názvov naznačuje tzv. Bavorský Geograf, ktorý po Čechoch spomína jedných Moravanov v podobe Marharii a neskôr pred Východnými Obodritimi, pochádzajúcimi z Potisia, resp. podla mena z Pobodrožia, iných Moravanov v podobe Merehanos (MMFH III 1969, 287-288).

Obe etnonymá sú ku germánskemu pomenovaniu rieky Moravy Maraha, ktoré vzniklo z hydronyma Marus, ako ho zaznamenali už rímski dejepisci, pridaním germánskeho ahwa „voda, rieka“, kde spoluhláska $w$ vypadla (pozri Kroonen 2013, 7). Otázkou však je, prečo v druhom názve vidíme doklad zmeny Maraha > Mereha-. Odpoved’ou na túto otázku je práve analýza mena moravského kniežata Rastislava, kde vidíme podobnú zmenu, a to Rastic > Restic, čo sú jediné isté zachované podoby jeho mena. Faktom totiž je, že moravský Rastislav sa v súdobých prameňoch zapisoval Rastislav len málokedy, ak vôbec niekedy.

V latinských Fuldských análoch sa meno Rastislav nevyskytuje ani raz. Moravský panovník sa v nich spomína k rokom 846 - 871 mnohokrát a vždy v podobe Rastiz, resp. Rastic (pozri MMFH I 1966, 90-103). V d’alších relevantných latinských textoch je to podobne, teda bez -slav. V Xantenských letopisoch na rok 870, ako i 871 sa uvádza ako Rasticius rex (MMFH I 1966, 68), v Bertinských letopisoch je k roku 861 cum Resticio Winidorum, Resticii, k roku 862 Resticio Winidorum, k roku 863 Restitio Winido, k roku 866 Restitio Winido, Restitius, contra Restitium, k roku 870 Resticium Winidum, Restitium Winidorum regulum, Restitii a k roku 871 Restitii (MMFH I 1966, 74-78). Reginonova kronika má k roku 860 Rastiz (MMFH I 1966, 136), Weingartenské letopisy k roku 870 Rastizius dux (MMFH I 1966, 136), Hildeishamské letopisy majú k roku 864 spotvorené Ratzidum, tak aj letopisy weissemburské či ottobeuernské, altaichské zas Razidum a podobne aj dalšie (MMFH I 1966, 136, 153, 154, 158).

Jediný starosloviensky prameň, ktorým je traktát mnícha Chrabra $O$ písmenách, uvádza meno nášho panovníka v tvare Rastica moravska, resp. Rasti c(ěsa)rę moravska (MMFH III 1969, 371). Chrabrov spis je však, naneštastie, dochovaný až v neskorších cirkevnoslovanských opisoch zo 14. - 17. storočia a v podobe, $\mathrm{v}$ ktorej je doložený, bol už zjavne upravovaný a doplńaný (MMFH III 1969, 364), takže ho sám osebe za úplne spolahlivý prameň antroponyma považovat nemožno. Toto platí tiež pre zápisy mena moravského kniežata v ruskej cirkevnej slovančine, kde sa spomína ako Rostislavz (pozri ESJS 13 2006, 752), pričom tieto datujeme do 12. - 13. storočia. Ešte mladšie sú potom cirkevnoslovanské zápisy Rastislavъ (pozri SJS III 1982, 616). Do 12. a 14. storočia datujeme podobne najstaršie rukopisy Legendy rímskej, kde sa nachádza latinizovaná podoba mena Rastislaus, Rastilaus (MMFH II 1967, 127).

Jednoznačne archaickú podobu antroponyma so -slav možno nájst̉ iba medzi zápismi mien návštevníkov kláštora z Cividalského evanjelia ako Rastisclao, čo je zápis, ktorý napríklad R. Stankov vo svojej nedávnej štúdii o moravskom antroponyme Rasticb/Rastislavo opomína (pozri Stankov 
2019, 349-370). A to asi preto, že mená sú v evanjeliu popísané tak trochu bez ladu a skladu, čím chceme povedat bez dostatočného kontextu, takže nie je isté, či tento zápis patrí ozaj moravskému Rastislavovi, aj ked' je to dost' pravdepodobné, lebo sa dá predpokladat, že ked' medzi pútnikmi boli Pribina, Kocel', Svätopluk s manželkou atd., bol tam i on (pozri MMFH III 1969, 332-333).

Dochované pramene nám v prípade, že tento predpoklad uznáme, umožňujú potom rekonštrukciu troch podôb mena následníka po moravskom Mojmírovi I.: predovšetkým zápis z Cividale, ale čiastočne i zápisy z ruskej cirkevnej slovančiny a latinskej Legendy rímskej ${ }^{\star}$ Rastislavø, zápisy z Bertinských letopisov ${ }^{\star} R$ ’ästicb a vel'ká väčšina latinských zápisov, ako i jediný starosloviensky prameň ${ }^{\star}$ Rasticb. Všetky tri sú historickojazykovedne zaujímavé, no kým druhá a tretia podoba sú isté a jasne kladú meno do oblasti strednej slovenčiny, prvá podoba ${ }^{\star}$ Rastislavo je neistá a neisté je aj jej zaradenie do tejto nárečovej oblasti. Dialektologicky totiž môže byt stredoslovenská, južnoslovanská a do úvahy pre ňu pripadá ešte pár menších praslovanských nárečových oblastí.

Na základe písomných prameňov však minimálne zápis Rastisclao z 9. storočia kladie nositela mena jednoznačne do Nitry, pretože ho do kláštora sprevádzal nejaký Nitrabor, ktorý je za ním v Cividalskom evanjeliu zapísaný hned’ ako piaty v poradí, i Gomer (pozri MMFH III 1969, 332333), ktorého meno zrejme poukazuje na hrad a župu Gemer, s prvým zápisom v roku 1198 Gomur (pozri viac Ondruš 1980, 276-277). Meno ${ }^{\star}$ Rasticb svojou patronymickou príponou -icb (porov. napr. SP 2 1976, 55-60) poukazuje na to, že mohol jestvovat' Rasticov otec s menom * Rastislavz, ktorý mohol byt v kláštore. Vylúčit však nemožno ani to, že súčasníci síce volali moravského panovní$\mathrm{ka}{ }^{\star}$ Rasticb, resp. ${ }^{\star} R$ 'ästicb, ale on sám sa nechal zapísat vo vznešenejšej podobe ${ }^{\star}$ Rastislavz. Takéto špekulácie, samozrejme, patria do onomastiky i širšej jazykovedy, ale tažko sa do nich púštat', ked' povaha zápisu je neistá a navyše analogických prípadov z moravského prostredia niet.

$\mathrm{Z}$ jazykovedného i historického hladiska je ovela istejšou podoba ${ }^{*}$ Rasticb $\mathrm{s}$ jej nárečovým variantom ${ }^{\star} R$ 'ästicb, ktoré smerujú rovnako ako nositel zápisu Rastisclao k Nitre. Z hladiska slovanskej dialektológie patria obidve podoby jednoznačne do západoslovanského nárečového makroareálu. Aspoň ak si budeme všímat príponu -icb a uznáme, že tento sufix antroponyma pochádza zo staršieho *-itjo (SP 2 1976, 55-60) a nie zo sémanticky i hláskovo možného, no v širšom onomastickom kontexte nepravdepodobného *-iko (SP 1 1974, 97). Sufix *-ìtjo je bežne známy predovšetkým z častých srbských, chorvátskych, ako i čiernohorských a bosniackych priezvisk $\mathrm{s}$ dnešnou príponou -ić či ruských alebo širšie východoslovanských priezvisk s dnešnou príponou -ič, ale rovnako tak aj zo slovenskej apelatívnej slovnej zásoby vo výpožičkách typu královič. Kým praslovanská spoluhlásková skupina ${ }^{\star} t j$ sa menila na srbské a chorvátske ć a východoslovanské $\check{c}$, v západnej slovančine sa menila na $c$, preto sa u západných Slovanov táto prípona, hoci je $\mathrm{v}$ ich pôvodných propriách ovela menej frekventovaná, vyvíjala ${ }^{\star}-i$ tjo $>-i c b>-i c$.

Západoslovanský sufix -icb v nami analyzovanom antroponyme ${ }^{\star}$ Rasticb značne obmedzuje možnosti, odkial mohol Rastic pochádzat. Ak opomenieme okrajovú etymológiu jeho mena k iránskemu rast- „správny, spravodlivý ap.“ (pozri viac ESJS 13 2006, 752), všeobecne sa akceptuje, že koreň Rast- antroponyma pochádza z praslovanského * orst- „rást“', ktoré sa zmenilo na južnoslovanské Rast- a na západoslovanské a východoslovanské Rost-. Jedinou velkou výnimkou je tu stredná slovenčina, preto má spisovná slovenčina Rastislav, kým čeština Rostislav, polština Rościsław, ruská cirkevná slovančina Rostislavz, ruština Rostisláv atd'. (pozri ESJS 13 2006, 752).

Jednoduchá úvaha nás potom privedie $\mathrm{k}$ tomu, že z dialektologického hladiska muselo byt’ ${ }^{*}$ Rasticb stredoslovenské meno, lebo príponu -icb < *ititjo mala len západná slovančina a v západoslovanskom nárečovom makroareáli zachovala len stredná slovenčina Rast- < ${ }^{*}$ orst-. Také jednoduché to však nebolo. Stredná slovenčina je síce jediným relevantným západoslovanským kandidátom zmeny praslovanského * ${ }^{*} T$ - na raT-v neakútových slabikách na začiatku apelatív, no niekolko jej dokladov nájdeme napríklad aj v českej toponymii. Uvádza sa takto Ralov, Rasochy, 
doložené už v stredoveku, Rastory, Raští, v roku 1373 zapísané ako Rasta, rovnako stredoveká Raveň a Rastely, uvádzané už v roku 1088 v podobe Rastileh. Stará čeština má navyše doložené aj apelatívum letorastl. Apelatívum je však ojedinelé a mohlo vzniknút vplyvom cirkevnej slovančiny a toponymá sa nachádzajú geograficky obmedzene, nie súvislo na celom českom území, akoby boli iba odrazom nárečia nejakého kmeňa, lokalizovaného najskôr v južných Čechách (pozri Vondrová - Blažek 2001, 316-318; Novák 1980, 53), takže daleko od Pomoravia, ako je dnešné moravské Slovensko, Záhorie a ich okolie, čo bola prvá Morava štátu s názvom Moravy. Zo slovenskej strany stredoveké formy typu Razowag 1212, Razwag 1245 končia nanajvýš pri Trenčíne (pozri napr. Ripka 1975, 34-35).

Druhá Morava štátu s duálovým názvom Moravy bola v Ponitrí. A práve širšie Ponitrie muselo byt tým územím, z ktorého pochádzal nositel’ mena ${ }^{\star} R a s t i c b$. Konečným argumentom, že Rastic pochádzal z Nitrianska, sú zápisy z Bertinských letopisov. Podoby Resticius, Restitius z tejto pamiatky reprezentujú formu ${ }^{\star} R$ 'ästicb, ktorú možno najlepšie vysvetlit zo strednej slovenčiny, kde je po zmene ra- > r'ä- > rä- aj dnes miestami bräda, kräj a räst' i riast', na čo upozornil už J. Stanislav (pozri Stanislav 1978, 50, 131-132).

Nitriansko a zadunajská Panónia ako potenciálne nárečové oblasti na rozhraní západoslovanského a južnoslovanského makroareálu, dnes by sme mohli čiastočne povedat stredoslovenské, môžu niesț i d’alší zaujímavý onomastický doklad zmeny ra- > r'ä- > rä-. Do blízkosti Nitry alebo do Panónie totiž možno klást’ pôvod svätého Gorazda, designovaného nástupcu arcibiskupa Metoda, o čom svedčí toponymia k jeho menu. V nej rovnako môžeme vidiet’ zmenu Gorazd- > ${ }^{*}$ Gorezd-, resp. Gerezd (vokálnou harmóniou, obvyklou o. i. aj v mad’arčine), pričom zaujímavé je predovšetkým toponymum Gerezd, doložené z roku 1480, v geografickej blízkosti toponyma Kazil, zapísanom v roku 1167, ktoré ukazuje na Pribinovho syna Kocela (pozri viac Krajčovič 2005, 122).

Izoglosu $r a \|$ rä teda vidíme i v antroponymách, nielen v etnonymách, resp. hydronymách či choronymách, ako boli uvedené dve Moravy ${ }^{\star}$ Maraha a ${ }^{\star}$ Mereha. Tieto dve Moravy, jednu v Pomoraví, druhú v Ponitrí, mali podla vel'kej väčšiny historikov svojho času ovládat Mojmír II. proti nitrianskemu Svätoplukovi II., Mojmír I. proti nitrianskemu Pribinovi a proti nitrianskemu Svätoplukovi I. mal stát Rastislav. Faktom ale je, že písomné pramene spájajú iba Pribinu s Nitrou v čase Mojmíra I. a Svätopluka I. na sklonku jeho života s nitrianskym Zoborom, takže tento predpoklad je založený len na nepriamych indíciách. Jazykovednou indíciou potom je, že v čase nitrianskeho Pribinu žil v ponitrianskej Morave aj Rastic, kedže jeho meno je stredoslovenské a Nitra stojí dnes na rozhraní západnej a strednej slovenčiny.

Samotný Pribina pochádzal z Nitry, alebo tam prinajmenšom bol významnou postavou v časoch Mojmíra I. Jeho meno navyše poukazuje na možnú spojitost' s Rasticom. Ako už bolo uvedené, v predpokladanej hlavnej línii Mojmírovcov, teda Mojmír I. - Svätopluk I. - Mojmír II./ Svätopluk II., môže priamu rodovú spojitost̉ medzi nositel'mi mien naznačovat' nielen ich opakovanie, lež i sémantika, kedže je rovnaká: meno Mojmír pochádza z * Mojiměrr „slávny, znamenitý svojimi“ a Svätopluk zas zo *Svętopzlkz/*Svętěpzlkz, čo rovnako znamená „slávny, znamenitý svojimi“. Meno Rastislav je však odlišné a značí „slávny rastom“. Podobnú sémantiku vidíme napríklad v prvej časti mien ako Pribychval, Pribygoj, Pribyslav, Pribymir, ktorá odkazuje na pribúdanie (pozri Niederle 1916, 155). Antroponymá Pribyslav, Pribymir ap. by takto boli synonymné s menom Rastislav. Sem potom patrí tiež meno nitrianskeho a panónskeho kniežata Pribina, kde je rovnaký koreň slovesa pribyti „pribudnút“. Na pôvodné čítanie [y] (akoby [ü] = [ui]) ukazuje napríklad už autentický zápis jeho mena za Kocelovým z Cividale: Quocili, Priuuina (MMFH III 1969, 333), hoci Pribina s - $i$ - sa správne vykladá odsunutím - y z koreňa priby- a pripojením sufixu -ina (pozri Krajčovič 2005, 38). 
Sufix -icb mohol byt patronymický, ako sme už spomenuli, ale tiež deminutívny (porov. napr. SP 2 1976, 55-60). Ked' zoberieme do úvahy, že mnohovýznamová prípona -ina bola okrem iného rovnako deminutívna (porov. napr. SP 1 1974, 120-123), otvára sa nám určitý onomasticko-sémantický priestor na hypotézy o priamom rodinnom vztahu Rastica s Pribinom. Treba však zdôraznit, že nie je podporený, ako je to v prípade Mojmíra I. a Svätopluka I., antroponymami z Pribinovho nespochybnitelného príbuzenstva, ktorým je vlastne iba nositel' mena Kocel', pričom pôvod tohto nie je celkom jasný. Pravdepodobnejšie sa preto z jazykovedného uhla pohladu javí, že prípona -icb bude v prípade mena ${ }^{*}$ Rasticb patronymická a poukazovat potom na Rasticovho otca či predka Rastislava, možno práve toho, ktorý je v podobe Rastisclao zapísaný v Cividalskom evanjeliu a ktorý má vztah k Nitre cez Nitrabora.

Netreba však zabúdat ani na to, že Rastic v rámci bojov Karlomana proti královi Ludovítovi, svojmu otcovi, Pribinu zabil (porov. Steinhübel 2004, 122) a celkový vztah medzi Rasticom a Pribinom ukazuje na nezmieritel'né nepriatelstvo, takže vzhladom na priam vražedné pomery medzi Rasticom a jeho blízkym príbuzným Svätoplukom I. či medzi bratmi Mojmírom II. a Svätoplukom II. rodinný vztah medzi Pribinom a Rasticom vylúčit’ nemožno. Rasticovo prenasledovanie Pribinu doslova až za hrob by mohlo paradoxne svedčit o príbuzenskej línii, lebo by malo zdôvodnenie v Rasticovom strachu zo straty moci alebo v jeho túžbe po jej zväčšení, oboje na základe nejakého rodového práva či legitimity. Na to, že Pribina bol mojmírovec, poukazuje tiež to, že v čase vyhnania nebol ešte označený slovom $d u x$ „knieža“, lež quidam „akýsi“, ako aj úspech Mojmírovej akcie u krála L’udovíta II. Nemca, ktorého bol inak, aspoň neskôr, Pribina chránencom (MMFH III 1969, 310-311).

$\mathrm{Na}$ záver našej štúdie už len zhrnieme, že meno Rastislav medzi moravskými panovníkmi asi vôbec nefigurovalo. Rovnaká sémantika antroponým Mojmír a Svätopluk môže naznačovat’ priamu rodovú spojitost medzi ich nositelmi, pričom túto potvrdzuje najmä to, že Svätopluk I. bol otcom synov s menami Mojmír a Svätopluk. Táto hypotetická myšlienka je zaujímavá v súvislosti s tým, že meno nástupcu Mojmíra I. nebolo zrejme Rastislav, ale skôr Rastic. Prípona -ic môže byt bud' patronymická, čím by poukazovala, že Rasticovým otcom bol nejaký Rastislav, alebo deminutívna, čím by meno Rast-ic mohlo byt významovo identické s Prib-ina a poukazovat na nejakú vedlajšiu vetvu Mojmírovcov, čo by bol teda podobný prípad sémantického stotožnenia ako v prípade Mojmír - Svätopluk. Sémantika antroponým * Rasticb a Pribina však rozhodne nemôže byt pri takýchto historických hypotézach klúčcovým argumentom a musíme sa na ňu pozerat ako na špekuláciu bez dostatočnej opory.

Isté pri mene Rastic je iba to, že sufix -ic je západoslovanský a koreň Rast-najmä južnoslovanský a stredoslovenský, takže antroponymum Rastic je v dnešnej terminológii najskôr stredoslovenské, čo potvrdzuje tiež jeho podoba ${ }^{\star} R$ 'ästicb. Na základe relevantných písomných prameňov je možné v rámci Moráv lokalizovat iba Pribinu na začiatku kariéry do Nitry a Svätopluka na konci života do Nitry. Na základe skúmania vel'komoravských antroponým je zas možné spojit Rastica na začiatku života s Nitrianskom. Párovanie vel'kej väčšiny historikov typu pomoravský Mojmír I. proti ponitrianskemu Pribinovi, pomoravský Rastislav proti ponitrianskemu Svätoplukovi I. a pomoravský Mojmír II. proti ponitrianskemu Svätoplukovi II. sa ukazuje byt’ o čosi zložitejšie, ako sa zvyklo celé desatročia tradovat', pretože Mojmírovci z Pomoravia by nemali dôvod pomenúvat’ potenciálneho následníka trónu ponitrianskym nárečím. Toto je aj hlavný záver predloženého jazykovedného výkladu o pôvode moravského Rastislava. 


\section{REFERENCES}

ESJS 13. 2006. Etymologický slovník jazyka staroslověnského 13. Praha, 751-814.

Krajčovič, Rudolf. 2005. Živé kroniky slovenských dejín skryté v názvoch obcí a miest. Bratislava. Kroonen, Guus. 2013. Etymological Dictionary of Proto-Germanic. Leiden - Boston.

MMFH I - Magnae Moraviae fontes historici I. 1966. Praha - Brno.

MMFH II - Magnae Moraviae fontes historici II. 1967. Brno.

MMFH III - Magnae Moraviae fontes historici III. 1969. Brno.

Niederle, Lubor. 1916. Slovanské starožitnosti. Díl II. Svazek 1. Základy kulturních starožitností slovanských. Víra a náboženství. Praha.

Novák, Ludovit. 1980. K najstarším dejinám slovenského jazyka. Bratislava.

Ondruš, Šimon. 1980. Pôvod názvov slovenských vrchov, hradov a stolíc. In Studia Academica Slovaca 9. Bratislava, 261-283.

Pukanec, Martin. 2020. K menám priamej línie Mojmírovského domu. In Acta onomastica LXI/1, 185-193.

Ripka, Ivor. 1975. Dolnotrenčianske nárečia. Bratislava.

SJS III. 1982. Slovník jazyka staroslověnského III. Praha.

SP 1. 1974. Słownik prasłowiański. Tom 1. Wrocław - Warszawa - Kraków - Gdańsk.

SP 2. 1976. Słownik prasłowiański. Tom 2. Wrocław - Warszawa - Kraków - Gdańsk.

Stanislav, Ján. 1978. Starosloviensky jazyk 1. Vel'ká Morava a Panónia. Kultúrny jazyk a písomníctvo. Konštantín Filozof, Metod a Kliment sloviensky. Fonetika. Bratislava.

Stankov, Rostislav. 2019. Проблема лексических моравизмов и имя моравского князя: Растиць или Растиславъ [The problem of lexical moravisms and the name of Moravian prince: Rasticь or Rastislavъ]. In Славянское и балканское языкознание. Палеославистические чтения 2 [Slavic and Balkan Linguistics. Paleoslavistic Texts - 2]. Moscow, 349-370.

Steinhübel, Ján. 2004. Nitrianske kniežatstvo. Bratislava.

Vondrová, Marcela - Blažek, Václav. 2001. Slovanské archaismy a dialektismy v toponymii Čech. In Čeština - univerzália a specifika 3. Brno, 311-342.

SUMMARY: ON THE ORIGIN OF RASTISLAV OF MORAVIA FROM A LINGUISTIC POINT OF VIEW. This paper deals with three names of the successor to the throne after Mojmír I, ruler of Great Moravia, in the historical records: ${ }^{\star}$ Rastislavo,${ }^{*}$ 'ästicb and ${ }^{\star}$ Rasticb. The Late Proto-Slavic personal name ${ }^{\star}$ Rastislavz of the Great Moravian ruler is doubtful. The names ${ }^{*}$ R'ästicb and ${ }^{*}$ Rasticb are Central Slovak because Proto-Slavic ${ }^{*}-$ itjo $>$ West Slavic (including Central Slovak) -icb and Proto-Slavic * orst- > South Slavic as well as Central Slovak Rast-, and Central Slovak ra- > r'ä- > rä- (cf. Central Slovak räst', riast). This fact has many historical consequences, the most important of which is the origin of the so-called Rastislav

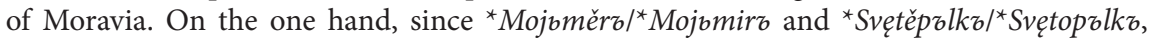
names of the direct line of Great Moravian rulers, both mean the same (the first personal name is reinterpreted as ${ }^{*}$ Mojimér $r$ Proto-Indo-European * moios "my (regiment, house)" +

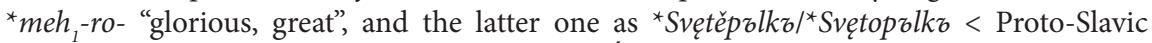
${ }^{*}$ svęt "glorious, great" < Proto-Indo-European ${ }^{*} k$ wen- "to celebrate" + Proto-Slavic *-pəlkz "regiment, house"), as well as Rastic, name of the indirect line of Great Moravian rulers, and Pribina, name of a leader of Merehanos, both mean the same, Rasticb/R'ästicb could be a relative of Pribina. On the other hand, prince Rasticı/R'ästicb could be a son of Rastislavъ. The latter is more probable from a linguistic point of view. 
Martin Diweg-Pukanec

doc. Mgr. Martin Diweg-Pukanec, PhD.

Constantine the Philosopher University in Nitra

Faculty of Arts

Department of Slovak Language and Literature

Štefánikova 67

94974 Nitra

Slovakia

mdpukanec@ukf.sk 